\title{
Why Church Leaders Discourage Christians from Leaving Jordan: An Anti-Emigration Perspective
}

\author{
Lucy Schouten \\ PhD Candidate, Centre for the Study of World Christianity, \\ School of Divinity, University of Edinburgh, Edinburgh, UK \\ Lucy.Schouten@ed.ac.uk
}

\begin{abstract}
Migration and refugee displacement are some of the most pressing issues facing the contemporary Middle East. Regional church leaders have cautioned against Christian emigration from ancient Middle Eastern churches to countries outside the Middle East; even Christian refugees who have already been displaced internally within the region are often discouraged from leaving. This article surveys some of the public statements that discourage Middle Eastern Christians from leaving the region, as presented from various denominational perspectives. Building on fieldwork conducted in Amman, Jordan, in 2018 and 2019, the article then argues that the attempts by Arab Anglican leaders in Jordan to dissuade church members from emigrating are based on a particular self-understanding of Middle Eastern Christianity that emphasizes an active, continuing Christian presence within the Middle East, as well as practices of unity among different Christian communities and longstanding coexistence with Muslim neighbors.
\end{abstract}

\section{Keywords}

Middle East - Jordan - migration - refugee - Anglican - humanitarian aid

The Middle East is an important context for World Christianity studies of migration, as it is a region where Christianity has a long history, even though the churches have become numerically small because of past conversions and 
migration. ${ }^{1}$ While emigration is a key issue for churches in the Middle East, studies focusing on the migration concerns of Middle Eastern churches are scarce, even among literature that addresses global Christian migration. For example, Migration and Public Discourse in World Christianity, edited by Afe Adogame, Raimundo C. Barreto, and Wanderley Pereira da Rosa, is concerned primarily with migrants' experiences upon arrival to a new location, often in the Global North. ${ }^{2}$ The book's theological proposals are directed toward the churches that welcome new immigrants, but Middle Eastern churches are absent from the volume. Another relevant compilation, edited by Susanna Snyder, Joshua Ralston, and Agnes Brazal, is Church in an Age of Global Migration: A Moving Body, which seeks to understand how migration transforms churches. Two chapters that focus on the Middle Eastern context offer reflections on the plight and agency of migrant Christians who leave the Philippines to work in the Gulf and Lebanon. ${ }^{3}$ This volume and most other studies on the subject of Christian migration, however, lack discussion specific to the churches native to the Middle East, which are host to many Christian refugees from within the region, and from which many migrants continue to depart. ${ }^{4}$

For many years now, global and regional church leaders have noted with concern that Christians are leaving the Middle East at much higher rates than their neighbors in the Muslim-majority region. Scholarship has identified numerous factors for these migratory patterns, such as job opportunities due to the comparatively high education rates among Christians, economic ambitions, and

1 Scholarly discussions about the hitherto-limited presence of the Middle East within the field of World Christianity may be found in the following: Deanna Ferree Womack, "Transnational Christianity and Converging Identities: Arabic Protestant Churches in New Jersey," in Religion, Migration and Identity: Methodological and Theological Explorations, (eds.). Martha Frederiks \& Dorottya Nagy (Leiden; Boston: Brill, 2016), 112-131; Laura Robson, "Recent Perspectives on Christianity in the Modern Arab World: Christianity in the Modern Arab World," History Compass 9/4 (2011), 312-325.

2 Afe Adogame, Raimundo C. Barreto, \& Wanderley Pereira da Rosa (eds.), Migration and Public Discourse in World Christianity (Minneapolis: Fortress Press, 2019).

3 Agnes M. Brazal and Randy Odchigue, "Cyberchurch and Filipin@ Migrants in the Middle East," in Church in an Age of Global Migration: A Moving Body Pathways for Ecumenical and Interreligious Dialogue, (eds.). Susanna Snyder, Joshua Ralston, \& Agnes M. Brazal (Houndmills, Basingstoke, Hampshire; New York, NY: Palgrave Macmillan, 2016), 187-20o.

Daniel Chetti, "Vulnerable and Missional: Congregations of Migrant Domestic Workers in Lebanon," in Church in an Age of Global Migration: A Moving Body Pathways for Ecumenical and Interreligious Dialogue (eds.). Susanna Snyder, Joshua Ralston, and Agnes M. Brazal (Houndmills, Basingstoke, Hampshire; New York, NY: Palgrave Macmillan, 2016), 201-216.

4 Another work with a particular focus on migration within World Christianity, albeit lacking extensive discussion of the Middle East, is Peter C. Phan (ed.), Christian Theology in the Age of Migration: Implications for World Christianity (London: Lexington Books, 2020). 
fear of religious persecution in the Middle East. ${ }^{5}$ Decades, even centuries, of such emigration have gradually diminished the numbers and strength of the ancient churches across the Middle East. This is increasingly true even of the relatively stable nation of Jordan, the focus of this study. Noting the decline of church populations with dismay, Middle Eastern church leaders have actively discouraged Christians from emigrating and leaving the region, as the next section will describe in greater detail.

This article explores how and why church leaders discourage both indigenous Christians and Christian refugees from leaving the Middle East. I will first present several statements from Protestant, Catholic, and Orthodox leaders who publicly urge Christians to remain in the Middle East as a matter of Christian faith. Next, I will provide a case study on Jordan which exemplifies how some Christian leaders have approached this issue on the ground. The case study draws on fieldwork in Amman, Jordan, in 2018 and 2019 that shows how local Anglican leaders encourage local members and Syrian and Iraqi Christian refugees to remain in Jordan. ${ }^{6}$ The article argues that this drive to discourage migration stems from a distinct self-understanding of Middle Eastern Christianity. This understanding is based on three elements, which will be addressed in detail in sections 4,5 , and 6 . These are, first, an emphasis

5 Scholarship on the emigration of Christians from the Middle East has been extensive. Useful works on this subject, and on Middle Eastern Christianity broadly, include the following: Dawn Chatty, Displacement and Dispossession in the Modern Middle East, The Contemporary Middle East 5 (New York: Cambridge University Press, 2010); Mohammed Girma \& Christian Romocea (eds.), Christian Citizenship in the Middle East:Divided Allegiance or Dual Belonging? (London; Philadelphia: Jessica Kingsley Publishers, 2017); Anthony O'Mahony (ed.), Eastern Christianity: Studies in Modern History, Religion and Politics (London: Melisende, 2004); Paul S. Rowe, John H.A. Dyck, \& Jens Zimmermann (ed.), Christians and the Middle East Conflict Routledge Series in Religion and Politics (New York: Routledge, 2014); Kenneth R. Ross, Mariz Tadros, \& Todd M. Johnson (eds.), Christianity in North Africa and West Asia, Edinburgh Companions to Global Christianity (Edinburgh: Edinburgh University Press, 2018).

6 I visited Jordan for two weeks in both February 2018 and February-March 2019, and I resided in Amman from June to October 2019. I undertook these visits to research the response of Jordan's churches to the current refugee crisis. My interviews and participant observations were conducted in a mix of English and Arabic, with a bias toward colloquial Jordanian Arabic. I identified myself as a researcher before interviews and upon entering churches for participant observation. The quoted church leaders gave permission for their views to be utilized in my research. Participant observation included not only lay involvement in church services and programs, but also voluntary service in the church's ministry. This serviceprimarily teaching or assisting with English classes-was planned in consultation with local church leaders, and interaction with any of these ministries was completely voluntary on the part of the church membership. In keeping with standard ethical practice for such research, I have omitted or altered the names of those described in the article and I have provided personal details only as necessary. 
on an active Christian presence in the land where the faith was founded; second, a functional unity among the various Christian groups in the Middle East, despite longstanding differences; and third, a sense that ongoing coexistence alongside a Muslim majority is a positive achievement of the Middle Eastern Christian experience.

\section{$2 \quad$ Background on Middle Eastern Christianity}

A note on the denominational diversity of Middle Eastern Christianity is necessary to introduce the topic of Middle Eastern church leaders' responses to migration. The Middle East is home to Christianity's oldest churches, with distinctive traditions that came into existence in the early centuries of Christian history, sometimes amidst bitter theological divisions, and ultimately spread across the region. These included the Eastern Orthodox Church, which remains prominent across Jordan, Syria, and Palestine to this day; the (Assyrian) Church of the East, still located in Iraq and eastward; the Maronite Catholic Church in Lebanon; the Syriac Orthodox Church, now based mostly in Syria and Iraq; the Coptic Orthodox Church in Egypt; and the Armenian Apostolic Church, which is scattered among all the Middle East's Christian communities. After the arrival of Roman Catholic missionaries to the region in the modern period, the Chaldean Catholic Church became the largest denomination in Iraq; Greek Catholic, Armenian Catholic, and Coptic Catholic Churches were also established around the region. In the nineteenth century, Protestant missionaries from Europe and North America established new churches too. Some of the earliest of these were the Anglican Church in what is now Palestine and Jordan and the Presbyterian Church in Syria and Lebanon.

Most of the above-named churches, and many others, are present in modern-day Jordan, although the Eastern Orthodox Church-also known as Greek Orthodox or Arab Orthodox-remains the oldest and largest, with an estimated 70,000 members, making up 62 percent of Jordan's Christian population. ${ }^{7}$ Some of the Middle East's churches maintain significantly different beliefs; others are divided only by their particular heritage and historic geography. While to an increasing degree, many of the Orthodox and, to a lesser extent, the Catholic churches, accept one another as fellow Christians,

7 “Jordan," in World Christian Encyclopedia, 3rd ed., (eds.). Todd M. Johnson and Gina A. Zurlo (Edinburgh: Edinburgh University Press, 2020), 438-440. The total Christian population for 2020 is 129,000, with the second largest group in Jordan being Catholics, with 29,000 adherents. 
many of the Protestant churches are perceived with a certain amount of disdain and mistrust because of "sheep-stealing," the evangelical practice of converting Orthodox Christians to their own, more recently established churches. Although such suspicions and older theological divisions continue to keep the churches apart, one source of unity among Middle Eastern church leaders has been their pressing concern about Christian emigration from the region.

\section{3}

\section{Church Leaders Discourage Christian Emigration}

Jean Corbon's work on the long and diverse history of Middle Eastern Christianity identifies a history and self-understanding distinctive to the Middle Eastern churches. This understanding helps to explain why Jordanian and other Christian leaders in the region today are so vocal about the dangers of emigration. ${ }^{8}$ Corbon argues that Middle Eastern church leaders are concerned about emigration because it weakens the already fragile presence of Christianity in the Middle East and further impoverishes the spiritual vitality of the churches, shaped through their unity amidst diversity, witness of Christ, and practice of Christian-Muslim relations. In order to account for both the divine foundations of the churches and the human context of the Muslim-majority Middle East, Corbon reviews these churches' long history, their diversification, and their identities as shaped by their "inheritance from the past." ${ }^{\prime \prime}$ With this foundation laid, Corbon then describes the problems facing the churches in the form of emigration, the difficulty of bearing witness to Christ in an interfaith context, and the challenge of intra-Christian relations among churches with such long and often bitter histories.

Emigration complicates all of these challenges, Corbon argues. Indeed, the goal of the Middle Eastern Council of Churches (MECC) upon its founding in 1974 was the survival of Christianity in the region. The Council's major principle was "presence," and church leaders denounced the emigration of Christians from the Middle East at that time as "a suicidal form of genocide."10 These statements from the MECC's Orthodox, Catholic, and Protestant leadership offer an important window into the anti-emigration stance of the region's religious leaders that began in the late twentieth century and continues up to

8 See Jean Corbon, "The Churches of the Middle East: Their Origins and Identity, from their Roots in the Past to their Openness to the Present," in Christian Communities in the Arab Middle East, (eds.). Andrea Pacini (Oxford: Oxford University Press, 1998).

9 Ibid

$10 \quad$ Ibid., 106. 
present. Thus, Corbon describes several key principles these leaders uphold: first, an active presence in the region, as opposed to emigration or withdrawal from public life; second, a unique notion of unity amid diversity and difference across the Middle East; and third, a tradition of Christian-Muslim dialogue.

Although Corbon's work was published in 1998 and focuses primarily on the various families of Orthodox churches, his understanding of Middle Eastern Christianity has continuing relevance for my study of Christianity in presentday Jordan. This can be seen in the case study on Jordanian Anglican leaders analyzed in the sections below, and also in public statements from a variety of mainline church leaders who discourage Christians from leaving the Middle East. Arab Protestant leaders, for example, have discouraged emigration in both ecclesiastical and pastoral settings as a sign of commitment to a Christian presence in the Middle East. Munib Younan, then-Bishop of the Evangelical Lutheran Church in Jordan and the Holy Land, addressed the issue at a conference for Arab Protestant church leaders in Amman, titled "The Evangelical Reformation and the Middle East: A Way Forward", as follows: "I thank God that your churches, despite all of what you have faced in the last year, will remain steadfast in witnessing to the gospel of love in the Middle East without any kind of fear." He acknowledged that problems in Syria, Iraq, Palestine, and Egypt have "obliged" some to emigrate, but he commended the faith of Iraqi Christians who returned to their destroyed churches after the defeat of Daesh (the Arabic name for ISIS). Younan also recognized "times of tribulation and persecution" in the Middle East, but he insisted that, "[w]hat comforts us is the steadfastness of Christians that remain on their land in the Middle East, who never lost hope in Jesus Christ."11 Such a statement, which he has repeated on other occasions when speaking publicly to church members, emphasizes the importance Younan attaches to maintaining an active Christian presence in the Middle East. ${ }^{12}$

It is important to note that this position on migration predates the wars of the last decade. For example, a statement released by a Synod of Catholic Bishops, which met at the Vatican in 2009, identified emigration as a key challenge facing the churches of the Middle East. The bishops declared, "Where, on the one hand, global politics will likely have an impact on a decision to

\footnotetext{
11 Munib Younan, "Though We Are Many, We Are One Body," The Evangelical Lutheran Church in Jordan and the Holy Land (4 October 2017). http://www.elcjhl.org/though-we -are-many-we-are-one-body/ (accessed 4 August 2020).

12 For another example illustrating the ways that Arab Protestant leaders encouraged members to remain in the Middle East, see Munib Younan, "Resurrection Joy in a Fearful World," The Evangelical Lutheran Church in Jordan and the Holy Land (15 April 2017). http://www.elcjhl.org/easter-message-from-bishop-younan/ (accessed 4 August 2020).
} 
stay in our countries or emigrate, on the other hand, accepting our vocation as Christians within and on behalf of our societies will be the paramount reason to remain and witness in our countries. At one and the same time, it is a question of politics and faith."13 The bishops argued, however, that an awareness of the importance of Christian presence in the Middle East would motivate Christian laity to remain in the region for the sake of their faith:

Another approach to limit emigration might be to make Christians better aware of the significance of their presence in a given country, where each Christian is to bear the message of Christ, a message which is to be proclaimed despite difficulties and persecution. In the Gospel, Christ states: 'Blessed are you when men revile you and persecute you and utter all kinds of evil against you falsely on my account. Rejoice and be glad, for your reward is great in heaven, for so men persecuted the prophets who were before you' (Matt. 5: 11-12). This then is the ideal which, with Christ's help, we must achieve. ${ }^{14}$

Thus, these leaders understood Middle Eastern Christianity as having a geographically grounded importance in the region, above their valid fears of political instability or economic interests. ${ }^{15}$

As these statements demonstrate, many of the region's churches and their leaders represent Middle Eastern Christianity according to a grounded understanding of place. Across denominational boundaries, Middle Eastern Christians draw strength and meaning from their place of origin, due to its historic significance within Christianity. The sections that follow will further explore this issue of emigration for both local Christians in Jordan and Christian refugees to determine how this issue is addressed by church leaders on the ground. Although the statements above are taken from leaders from a variety of churches, the sections below present a case study drawn mainly from Anglican churches. ${ }^{16}$ The next three sections will analyze the results from my 2018-2019 fieldwork in Amman, Jordan, using the framework of elements that

13 Synod of Bishops: Special Assembly for the Middle East, "The Catholic Church in the Middle East: Communion and Witness" (Vatican City, 2009) A-87. http://www.vatican .va/roman_curia/synod/documents/rc_synod_doc_20o91208_lineamenta-mo_en.html (accessed 1 August, 2020).

14 Synod of Bishops, B-4:27.

15 The full context of this quote can be found in Synod of Bishops, B-4:25-27.

16 Jordan is home to an estimated 3,80o Anglican Christians. Protestant denominations, as a whole, represent roughly nine percent of Jordan's Christians. See: Johnson and Zurlo, World Christian Encyclopedia, 438, 440. 
Corbon identified: presence in the Middle East, unity within Christian diversity, and relationships with Muslims.

\section{Presence in the Middle East}

As identified in the church leaders' statements above, the historic presence in the faith's birthplace is an important part of many Middle Eastern Christians' self-understanding. Indeed, "presence" was chosen as an early focus of the MECC for this very reason. "Presence" suggests that Christian faith is expressed not only in a particular way, but also in a particular place. For the Anglicans and other church leaders in Jordan who hold to this understanding, that place is the entire Middle East. Naturally, then, migration from the region threatens this understanding and must thus be discouraged. This notion of presence, which represents a geographically grounded understanding of Middle Eastern Christianity, will be examined in this section in relation to questions of migration.

I approached Reverend Hanna, a priest at a large Anglican church in Amman, with a request to learn more about his congregation's ministry to refugees. Receiving no response to an email, I eventually found him leading a worship service at a large, Arabic-speaking Anglican congregation in the center of Amman. He preached on Christ's miracle of calming the storm on the Sea of Galilee, when Christ asked his disciples, "Where is your faith?" Rev. Hanna's sermon noted that the Sea of Galilee was near at hand, and that today's Christians still needed faith to face the frightening difficulties of war and conflict. He specifically mentioned the particular politics relevant at the time and compared them to the scriptural passage. The sermon also pointed repeatedly to the geography of the region and the physical nearness of these miracles to the place where his congregation now sat.

After this service, Rev. Hanna admitted to me that he had not responded to my email because he received many such requests. He also asked for a detailed explanation of my faith and educational background and purpose, including a referral from a neighboring church leader he knew, before agreeing to help me. "It is good to meet Americans who are concerned about Christ," he said with a wry smile. "We know many are not. But don't worry, we are praying for you over in America."17

Along with his comments about the alleged disinterest in Christ "over in America," Rev. Hanna also demonstrated his awareness of common American

17 Interview by author, Amman, Jordan, February 2019. 
and European perceptions about Middle Eastern Christianity. He noted that many foreign researchers approached him for information about what they saw as a persecuted and struggling Middle Eastern church. He resisted this image, instead wishing to present a church defined by a long heritage of successful survival - an active Christian presence-in the region. His church, as he noted, could pray for Christians outside the region, including in my homeland. Thus, he subtly insisted that his church was a contributing actor within the Christian faith, rather than a frightened group of Christians who must soon emigrate to ensure their own survival. The Middle Eastern Christians in Rev. Hanna's view were not merely victims of religious persecution, repressive governments, or economic stagnation, but rather they were the living-or present-element within the long Christian history of the region. As his sermon noted, Rev. Hanna's church members had a proud heritage in the birthplace of the Bible, and the geography of Christianity was part of their inherited identity as Middle Eastern Christians.

This perspective influenced Rev. Hanna's approach to emigration. In a later interview, he described his church's efforts to minister to Christian Syrians and Iraqis who had fled conflict in recent years. The church leadership had sought homes for the refugees, they had prayed with them, and they had listened to the refugees' stories. When the trauma of the border crossing took the life of a newly arrived migrant, the Jordanian church had, with no small legal difficulty, given him a Christian burial in Jordan. "It is not as much as some people are doing, but it is what we can do," Rev. Hanna explained. "But one thing we will not do is to help anyone leave the Middle East."

Rev. Hanna's rejection of emigration for Jordanian Christians is notable, but it is more remarkable that he maintained similar sentiments about Syrian and Iraqi refugees in Jordan, even though it would seem self-evident that migration was their best option. These refugees had already fled their homes, their livelihoods, and even their countries. Many arrived in Jordan with few or no assets, and most were forbidden from seeking legal employment. This left them at the mercy of family and friends or the exploitative working conditions of the black market. Rev. Hanna and his fellow church leaders ministered to these refugees in their homes and churches and heard their stories, sometimes beginning years-long friendships with them. They were very well aware both of the difficulties that refugees faced in Jordan and of how much the refugees themselves wanted to leave the Middle East. Nonetheless, these leaders actively counseled the refugees to stay because they believed that the economic and political problems of the Middle East were less dangerous than the potential loss of their Christian heritage that they would face by leaving the Middle East. 
While historic divisions between the Middle Eastern churches have sometimes been bitter, a similar, if not precisely the same, historical experience of Christianity in the region over the centuries means that members of these churches share common social and cultural identities. Corbon emphasizes this when he claims, "The main factors which contributed towards the division of the Churches have in fact disappeared.... Nowadays, it is difficult to distinguish an Orthodox, a Catholic, or a Protestant on a social level."18 To be sure, this view must not be taken too far or misunderstood. Bitter histories separate the various Middle Eastern churches, as do differences in both worship and practice. This may be particularly true of Jordan, where centuries of struggle over the same resources created new and oft-cited grievances, as Mohanna Haddad has argued..$^{19}$ Important commonalities, however, do unite the Christians of the Middle East across their denominational lines, in what Corbon calls "unity within diversity." This phrase indicates that among different Orthodox, Catholic and Protestant denominations a functional camaraderie exists in the way that Christian leaders often cooperate with one another, Christian children attend school together in church-owned institutions, and Christian men and women from different denominations intermarry. ${ }^{20}$ This section will examine the way that this functional unity operates among the Anglican churches of Jordan, and will argue that it becomes apparent on the ground in Jordan in the way that Anglicans there discourage Christian emigration.

The particular setting of one interview I conducted with church leaders in Jordan demonstrates how a sense of unity became tangible despite differences. ${ }^{21}$ I had been invited to attend a regularly scheduled breakfast meeting of Amman's Anglican clergy. Three Anglican priests, as well as one female Arab Orthodox lay leader, were in attendance. They began by introducing themselves and their church and family backgrounds, adding with amusement that all of them were, on some level, foreigners. They explained that two

18 Corbon, "The Churches of the Middle East," 99-100.

19 For a scholarly discussion of the often tense history between Orthodox, Catholic, and Protestant churches in Jordan, see: Mohanna Haddad, "Detribalizing' and 'retribalizing': The Double Role of Churches among Christian Arabs in Jordan: A Study in the Anthropology of Religion," The Muslim World 1/2 (1992), 67-89.

20 Corbon, "The Churches of the Middle East," 94. By unity, Corbon does not mean that the daily lives of members or the worship services of the different church families are identical, or even that Christians from different churches and different countries are unaware or unimpressed by their differences.

21 Interviews by author, Amman, Jordan, February 2019. 
of the Anglican priests were Palestinians with Jordanian passports, educated in Lebanon but now serving in Amman. The third priest was born in the West Bank and currently served there, and he spoke as much of Christian-Israeli relations as he did of Islam. The female lay leader was of Palestinian origin too, and led a diaconate arm of the Arab Orthodox Church in Jordan with connections to the many Orthodox Arabs in Palestine. The four leaders' identities thus reflected the realities of many Jordanian Christians, nearly all of whom have family connections to Palestine. All spoke, throughout the discussion, with a broad consciousness of churches in Jordan and across the Middle East, whether Anglican, Orthodox, Catholic, Arab, or Armenian. The conversation also reflected their frequent ecumenical connections: lunches with Orthodox priests, awards given by a Roman Catholic (or Latin) Father, meetings with the Armenian church nearby. The Anglican leaders, in particular, served very diverse congregations. Few of their services were attended only by Arab Anglican Christians. Rather, their congregations included Chaldean Catholics from Iraq, Latins from Jordan, Syriac Orthodox Christians from Syria, Greek Orthodox Christians from Egypt, and Armenian Orthodox Christians from Lebanon and Iraq. ${ }^{22}$

I requested an interview with the group because the Anglican churches had offered relief for Syrian and Iraqi refugees since 2012. This humanitarian work included formal programs, such as medical clinics, that were open to anyone in need, as well as informal, pastoral help that was exclusive to Christian refugees. I began the interview by asking about the four leaders' understanding of a Christian duty to the stranger, and how this understanding influenced their work. At my question, however, the Orthodox lay leader blanched. "But they aren't strangers," she said, eyeing me skeptically. Then Rev. Hanna, who was hosting the discussion at his church, entered the debate. "The stranger, as we say, is my brother who I have not yet met," he interjected calmly, while the other priests nodded, as he alluded to Christ's scriptural command to visit the stranger.

In a number of ways, this exchange elucidates the concept of a working unity despite differences in both the Middle Eastern Christian setting and in the breakfast discussion itself. First, the discussion began at an Anglican church with an Orthodox Christian present, and the leaders' conversation revealed their active, friendly, and regular relationships with other Christian leaders in the area, regardless of denomination. Second, when I asked about the refugees they served, the group argued that the refugees were "not strangers," but rather they were brothers and sisters who, while new to Jordan, were 
already part of the Jordanian church community in some way. This was remarkable, because few, if any, of these Syrian and Iraqi refugees were Protestants. Most were Chaldean Catholics, Syriac Orthodox, or perhaps members of the Assyrian Church of the East. In fact, very few were baptized in churches that are officially in communion with either the Anglicans or the Arab Orthodox Church. Of course, a refugee need not be in communion with one's church to receive aid, the group agreed; many of these leaders had helped Muslim refugees as well. But the statement, "they aren't strangers," suggests that these Anglican and Orthodox leaders viewed the refugees as more than the recipients of charitable aid. They were new brothers and sisters, fellow-Christians who received pastoral support as such—and even partook of Holy Communion during Sunday services. ${ }^{23}$

Third, and finally, although three of the four leaders were born in Jordan, they did not identify themselves solely as "Jordanians." Rather, the three introduced themselves as being from various places, currently residents of Jordan, but ultimately as part of a broader Middle Eastern Christian family. This belief rested partly on their communities' memory of the historic dispersal of Palestinians from their homeland. As descendants of these Palestinian refugees, these leaders recognized that their forbears had left their homelands but believed that, by relocating to Jordan, they remained part of an important Middle Eastern Christian community. As they continued to preach in Arabic, to draw their congregations' attention to shared geography and customs with the Biblical landscape, they partook of what they saw as the inheritance of Middle Eastern Christianity. Although the differences among the Middle Eastern churches are significant, some form of the unity within a diverse Middle East that Corbon described was apparent in the way that my interviewees perceived the Syrian and Iraqi refugees as "not strangers"; rather Christian refugees were brothers and sisters whom they had not yet met who were entitled to receive pastoral support and Communion from Anglican churches. The church leaders believed that these Syrians and Iraqis were still at home, at least on some level, until they left the Middle East—and its connection to the earliest Christian history—behind.

The unspoken assumption was that these Syrian and Iraqi Christian refugees must have recognized this unity as well. If they had seen Anglican services as

23 I verified that non-Anglican Christians received communion at an Anglican Church during my participant observation research from June to October 2019 in Amman, Jordan. When asked, the presiding priest told me that he encouraged all baptized Christians from any church to receive communion, and he said that this was the position of the Anglican Church as a whole. 
invalid forms of Christianity, they could have avoided them entirely, as Syriac Orthodox and Chaldean Catholic churches were available in Jordan. The encounters between the Anglican priests, the Orthodox lay leader, and the Syrian and Iraqi refugees suggest an imaginary of unity and kinship that, at least amid the difficulties of forced displacement to Jordan, transcends the inherited and often bitter divides among Middle Eastern churches. It also transcends the national allegiances that divide Jordanian, Syrian, and Iraqi citizens, as the next example will demonstrate.

"We often talk about why we do this at the church," said Rev. Hanna, speaking about giving assistance to Iraqi and Syrian refugees. "We sometimes say that our true motivation for helping them is selfishness. This year, they come to us, but, well, we all know that maybe next year ..." The group chuckled grimly. The four leaders went on to explain that Christians in Jordan increasingly sought for a "Plan B" of imminent emigration to a foreign country, whether in Europe, North America, or Australia. This backup plan might be a spare passport tucked in a drawer, or a carefully nurtured contact at a foreign embassy. "We had a family meeting, and we all discussed it," the Orthodox lay leader explained uncomfortably. "All of my children decided that we must prepare to emigrate. What can I do"?

Christian unity was also on display in the relief work for refugees in Jordan. The church leaders' comments reflected a belief in a unity that connected them to Christians still in Egypt or Lebanon, or new arrivals from Iraq and Syria. For this reason, the leaders in the Jordanian churches, as well as the Palestinian priest who attended the meeting, wanted to discourage the emigration of all Middle Eastern Christians. Likewise, although officially of a foreign nationality, the Christians from Syria, Iraq, and Palestine were considered an active part of Jordan's congregations. The transition to church life in Jordan was certainly helped by their shared Arabic language and culture, although Armenians and Assyrian-speaking Christians from Iraq were also welcomed. They received help and fellowship as brothers and sisters, and these Jordanian priests believed that they and their congregants could anticipate similar aid if the situation were reversed, hence the joke about 'selfishness.'

Even though they had crossed national borders, Middle Eastern Christian refugees were considered to be part of the churches of Jordan after they arrived, and the leaders expressed a sense of loss when refugees chose to leave the region. In this way, these church leaders understood their identity as Middle Eastern Christians as connected to all of the historic Christian communities in the region. The concept of unity functioning amid denominational differences helps express an understanding of Middle Eastern Christianity that, at least where migration is concerned, appears to transcend the national 
differences and contentious theological history that may divide the churches at an official level.

Having established in the last section that a certain sense of unity can apply to Middle Eastern churches from different denominations and countries, I will next examine the ways that relationships with Muslim neighbors influence this lived self-understanding of Middle Eastern Christians and their concerns about migration. According to Corbon, the many centuries of coexistence alongside Islam is part of the Middle Eastern churches' "heritage." He argues that formal and informal Christian-Muslim dialogue, like Christianity itself, began in the Middle East. The nuances of this age-old dialogue are part of the inheritance of Middle Eastern Christians, whose active practice of interreligious dialogue is their gift to contemporary Christians around the world. Because positive Christian-Muslim relations cannot occur in a vacuum, a confident Christian presence is a prerequisite for this aspect of the Middle Eastern churches' heritage to continue. Such confidence, however, can be weakened by migration. This section will examine the connection that Anglican leaders noted between Christian-Muslim relations and migration.

Reverend Mark, one of the Anglican priests at the aforementioned breakfast gathering, maintained a pragmatic approach to Christian-Muslim relations in Jordan, and to the potential for Christian flourishing in the Middle East. While he was aware of tensions among Christians and Muslims in the area, he approached the situation with patience and confidence. On a personal level, Rev. Mark maintained cordial, working relations with Muslims in the neighborhood, many of whom respectfully addressed him as, "Abouna," upon seeing his clerical collar. ${ }^{24}$ On a more official level, he had studied Islam thoroughly enough to offer comparisons with "the Islamic interpretation" during the church's Bible Study meetings. He mentioned Islamic holidays in a neutral or

24 Abouna - Arabic for 'our father' - is the respectful title with which Arab parishes generally address Orthodox and Catholic clergy. As in other languages, the Arabic titles for Anglican clergy usually differ slightly, so "Abouna" was not precisely the correct address for Reverend Mark. The Orthodox and Catholic denominations have long predominated in Jordan, however, and many Jordanian Muslims are not aware of the differences among Christian denominations. The title nonetheless demonstrated polite deference to Christian religious authority. Rev. Mark appreciated this and saw it as evidence of respect among Christians and Muslims in the neighborhood. 
positive manner in his sermons, and he had developed an academic interest in Christian-Muslim relations during his postgraduate studies.

In the presence of fellow Jordanians, he described to me an incident that had occurred shortly after his installment in an Anglican Church in Amman. ${ }^{25}$ At that time, a group of Muslim boys had been throwing rocks at the front doors of the church. When he went out to confront them about the issue, he spoke calmly. This building, he told the boys, was God's house. Surely they would not wish to throw rocks at someone's house, especially God's? He invited them into the church as well. Although the boys did not accept his invitation to enter the church, the rock-throwing stopped.

When the Muslim boys disrespected the church building with their rockthrowing, this Anglican priest calmly entered into a conversation with them. Rev. Mark saw the incident in the context of the heritage of the Middle Eastern churches, which predated Islam but had also, as part of its rich history, developed the resources to live alongside Islam, as Corbon argued. The priest's actions and attitude signify the contrast between two approaches to Christian mission in the Middle East that Corbon identified when he wrote, "There are two temptations here: one is the centuries-old temptation to remain silent ... a reflection of prudence by a minority; the other is the very public proselytism carried out by the fundamentalist sects, which undermines the solidity of the apostolic Churches of the region and marginalizes them even more in the eyes of the Muslim authorities."26 Rev. Mark resisted both temptations in his approach. He acted confidently, as the caretaker of the church and a faithful Christian in Jordan, rather than as a frightened member of a persecuted minority who sees existential threats everywhere. He trusted that the long history of Christian-Muslim dialogue was part of his heritage as a Middle Eastern Christian. Although much of this heritage technically belonged to the region's various Orthodox churches, rather than to the Anglican Church, Rev. Mark considered this historical co-existence as part of his inheritance as a Christian in the Middle East who descended from centuries of earlier Christians.

When Rev. Mark told me all of this in the presence of others in his congregation, they appeared to me to be less impressed with the story than he intended. They showed signs of shock and dismay when they heard that boys had been throwing rocks at the church, and they looked rather alarmed when they heard that their priest had invited the boys into the church. It was clear that not everyone at the church shared Rev. Mark's sanguine appraisal of Christian-Muslim relations in the area. Nonetheless, he used this story to encourage others in

25 Interview by author, Amman, Jordan, October 2019.

26 Corbon, "The Churches of the Middle East," 107. 
the community, demonstrating his view that even perceived disrespect toward Christianity might be resolved through polite engagement and education, or in other words, through the organic Christian engagement with Muslim neighbors that was part of their collective heritage as Middle Eastern church members.

Such an ongoing Christian-Muslim dialogue requires a strong Christian presence to remain in the Middle East. The dialogue itself suffers when the Christian partner is weakened by migration, for it diminishes both Christian confidence and Muslim interest, not to mention the numerical loss of Christians participating in such a dialogue. For this reason, this priest's approach to Christian-Muslim relations in his area was pragmatic and concrete, and it played an important role in his approach to migration.

The complicated relationship between migration, Middle Eastern Christian heritage, and Christian-Muslim dialogue was demonstrated further in Rev. Mark's comments on the subject during another interview. When counseling the Iraqi refugees in his congregation, he had urged them not to migrate to Australia, despite their fears that problems with Muslims would force them to leave Jordan. He told me:

Our goal is everlasting life ... I tell them when they are thinking about leaving, 'If you feel oppressed by Islam here, who's to say that there you won't feel oppressed by atheism? Or even by work? They work very long hours there, and there may not be time to go to church.'27

In discouraging emigration, Rev. Mark argued that the Christian faithful may encounter many obstacles and trials, depending on the region in which they reside. He recognized that his congregants felt that pressure from a Muslim-majority society was a problem now, and perhaps one that could be avoided outside the Middle East. He argued, however, that a potential oppression by atheism or by the expectations of long working hours, even on Sunday, that are common outside the Middle East, could present a challenge to those who emigrated. All of these things, he argued, could endanger Christians spiritually.

For him, the question of whether a Christian should emigrate was largely a question of devotion to Middle Eastern Christianity, which was an essential aspect of his faith. Therefore, he enthusiastically urged all of the Christians in his congregation - both Jordanians and migrants - to stay in his church, or at least in the Middle East. While not unaware of the challenges facing Christians

27 Interview by author, Amman, Jordan, July 2019. 
in the region, Rev. Mark believed that Middle Eastern Christians were wellequipped to respond, so these challenges need not provoke alarm, nor did they necessitate emigration to a country where fewer Muslims resided. He maintained a pragmatic, faith-filled confidence in the future of Christians in Jordan and the Middle East more broadly, despite the challenges he encountered. $\mathrm{He}$ also encouraged the refugees in his church to demonstrate a similar confidence and faith by resisting the temptation to migrate yet again.

As Corbon argued and Rev. Mark's own life and ministry exemplified, Middle Eastern Christians have a long history of living alongside Muslims and of conducting interfaith dialogue, in an informal sense. Dealing with the particular trials of life in a Muslim-majority country was part of their identity and heritage as members of Middle Eastern churches, and it was part of their particular, Christian path to 'everlasting life.' By contrast, in Rev. Mark's view, the migrant Christians who had left his congregation were disavowing their heritage. The result, which he noted when counseling Iraqi and Syrian Christian refugees not to emigrate, could be to diminish the identity of the church that remained and its possibility for maintaining fruitful relations with Muslims. The refugees' departure not would only leave gaps in the pews of the church in Amman, but in the broader community of Middle Eastern Christians whose self-understanding relies on the survival of churches in the region. These churches must feel strong and significant enough to maintain an active dialogue with Muslim neighbors, rather than perpetuating the fearful attitude that some Christian congregants displayed. Therefore, Rev. Mark, like his colleague Rev. Hanna, refused to use church resources to help refugees emigrate. These priests trusted in their faith, and in their community's ability to coexist alongside their Muslim neighbors, over and against the promises of foreign migration.

\section{Conclusion}

This article goes deeper than the public statements of the Middle East Council of Churches and other church leaders who discourage Middle Eastern Christian emigration, and instead, with a case study, it examines how Anglican leaders justify an anti-emigration stance on the ground. The interviews with congregational leaders in Jordan are significant, because those leaders work so closely with refugees and other church members who are trying to migrate, because they experience many of the refugees' difficulties firsthand, and because they expect to face the same dangers of forced displacement and deprivation, should circumstances change for the worse in Jordan. Despite church leaders' 
candid concerns about these issues, the fieldwork presented in this article suggests their determination to represent Middle Eastern Christianity as having present-day vitality, a long and distinguished past, and even a promising future in the region.

To help ensure this future, namely to ensure that Christians from a variety of different church traditions remained at home in Jordan, my interviewees actively discouraged Christians from leaving the region. They did so in three significant ways: first, they explicated the importance of the presence, rather than the absence, of Christianity in the Middle East as a whole; second, they drew strength from practices of unity among very different Christian traditions; and third, they confidently engaged with Muslim neighbors and encouraged other Christians to do the same, not in a fear for their survival, but in a living expression of their identity as Middle Eastern Christians. Other scholars with expertise in Middle Eastern Christianity will be interested to note, therefore, the ways in which principles identified decades ago in Jean Corbon's work remain in force in these three conclusions of the case study. Perhaps more interestingly, this article demonstrates that the commitment to an active presence in the region remains part of the contemporary pastoral ministry, even in ministry to refugees who have already left their homes in Iraq and Syria.

Further research could expand this understanding, particularly by interrogating the views of church leaders in the region who, unlike the interviewees in this case study, may actually encourage Christian refugees to emigrate. Comparable research from a setting such as Egypt, with its very large Coptic Orthodox community, or from some of the historically Christian-majority regions in Iraq, Syria, or Lebanon, would offer instructive comparisons, particularly of approaches to Christian-Muslim and intra-Christian relations. For any of these settings, including elsewhere in Jordan, further research is needed to better understand the sense of Christian unity that I observed, and to delineate the limits of this unity. Because Jordan has experienced fewer violent conflicts than neighboring Iraq and Syria and is currently a refugee-receiving rather than a refugee-producing nation, the strains on Christian communities and refugees in surrounding countries might be greater. Do leaders in Syrian or Iraqi churches also seek to discourage migration? If so, how do their arguments compare to those employed by the Jordanian leaders in this study? These questions would likewise benefit from further research.

Most of this article's informants are Anglican, but there is reason to believe that these findings apply more broadly than Anglican or even Protestant churches, first, because these findings match the conclusions of Corbon's study on Middle Eastern churches as a whole, with particular evidence drawn from Eastern and Oriental Orthodox Churches. Additionally, in my case study, 
both the comments from the Orthodox lay leader and the willingness of nonAnglican Syrian and Iraqi refugees to attend Anglican churches demonstrate a practical unity amid denominational differences. For their part, the Anglican leaders I interviewed articulated that these broad principles of Middle Eastern Christian unity appealed to their Protestant and non-Protestant congregants alike. Nonetheless, further research with a particularly Orthodox or Catholic focus could help to confirm, reject, or illuminate the implications for other communities inside Jordan and around the region.

This study also offers a unique perspective on migration for the broader study of World Christianity. While sociological, ethical, or theological studies that focus primarily on Christian refugees and host communities in the Global North are useful, this article highlights the circumstances and motivations particular to a more unusual and understudied context. This research shows that Jordan is both a site of departure for Christians who wish to leave the region, and a site of arrival for refugees who flee neighboring conflicts. As such, this research offers an important window into an overlooked facet of migration. In Jordan, the loss felt by churches in migrant-producing regions becomes apparent, as do some of the particular self-understandings and strategies employed by those who choose to stay in churches that other Christians have left.

This article argues that Anglican leaders continue their commitment to church participation and development in the refugee-producing region of the Middle East. These church leaders articulate both in formal statements and in pastoral guidance their commitment to an active Christian presence in the faith's original homeland. This Middle Eastern Christian understanding transcends theological and ecclesiastical boundaries and incorporates the shared experience of coexistence alongside a Muslim majority. Many circumstances have changed in the region since Middle Eastern clergy in the late twentieth century began naming emigration as a threat to Christian survival in the region. Yet these findings confirm that such appeals to maintain a historically grounded 'presence' in the birthplace of the Christian faith remain central to the anti-emigration stances of leaders today. 